Article

\title{
Houses Based on Wood as an Ecological and Sustainable Housing Alternative-Case Study
}

\author{
Jozef Švajlenka * (1) and Mária Kozlovská \\ Department of Construction Technology and Management, Faculty of Civil Engineering, \\ Technical University of Košice, Vysokoškolská 4, 04200 Košice, Slovakia; maria.kozlovska@tuke.sk \\ * Correspondence: ingsvajl@gmail.com or jozef.svajlenka@tuke.sk; Tel.: +421-55-602-4381
}

Received: 14 April 2018; Accepted: 7 May 2018; Published: 9 May 2018

check for updates

\begin{abstract}
Sustainability of cities is currently a much-debated topic. The trend in Central Europe we witness nowadays is that people are going back from the impersonal and restrictive conditions of tower blocks to the more natural and relaxed conditions of family houses. New approaches to urbanization in the context of the sustainability of cities can be characterized by their use of innovative technologies and energetically efficient and ecologically acceptable construction materials. Companies have substantially responded to this trend, meeting the demand by offering a wide range of solutions. Alongside the traditional and long-established construction materials (brick, concrete), including wood, companies are introducing modern, innovative, and viable construction alternatives. Modern methods of construction (MMC), to which modern houses based on wood belong, promote the idea and application of environmentally and energetically efficient constructions. Just as the construction process itself significantly contributes to the depletion of natural resources, the production of construction materials contributes to significant environmental pollution and greenhouse emissions (particularly $\mathrm{CO}_{2}$ ). Sustainability assessments of construction projects increasingly involve the use of methodologies which assess sustainability criteria throughout a product's Life-cycle. For our analysis of suburban housing clusters designed to serve as family houses, we chose an actual family house construction completed using a modern construction system based on wood. For the sake of comparing the modern construction method, we created an alternative model of a construction based on a traditional masonry construction system. The main objective of this contribution is to analyze selected variants of constructions in terms of environmental and economic sustainability characteristics, as part of a broader assessment of permanent sustainability, by applying the life-cycle assessment (LCA) and life-cycle cost (LCC) methodologies within specified assessment boundaries. A partial objective of this contribution is to point towards the ways of applying the LCA and LCC assessment methodologies, such as in the decision-making processes involved in alternative investment strategies for the construction of urban clusters in the context of sustainability.
\end{abstract}

Keywords: building; economic; environment; life-cycle assessment; life-cycle cost; life-cycle time; modern methods of construction; sustainability; wood; wood house

\section{Introduction}

According to Huttmanová [1] and Mederly [2], sustainability is currently reflected in almost every area of life [3]. Production areas are often expanded through sustainable growth [4]. However, sustainable development itself is relatively hard to define. Evaluating specific production and implementation processes in terms of sustainability is a complex process [5]. The objective of the sustainability assessment is to identify more appropriate development options that will not limit the future needs of humanity [6]. In principle, it is a matter of finding a new, 'healthier' type of 
progress which is more appropriate in terms of sustainability principles [7]. This new type of progress was defined as a state of global balance in which the population and capital are kept at a constant level, while the trends causing an increase or decrease in these variables must be carefully kept under control [8-10].

The definition of sustainability is not clearly presented, so it is not easy to define its principles or criteria. Based on the numerous publications in the field [11-13], it is possible to come up with a general formulation of the principles and criteria of sustainable construction. The principles and criteria fall into three categories: ecological, social, and economic [14,15].

Sustainability of cities is currently a much-debated topic. There is increasing talk of so-called 'new urbanism', a reaction to the consequences of massive suburbanization. This new set of ideas is based on using technological innovations and knowledge from various scientific fields with the aim to ensure a quality of life which can be sustained over a long period of time. New urbanism is also characterized by the use of innovative, energetically efficient, and ecological construction materials [16].

An example of promoting sustainable housing is a project launched in 2003 by WWF [17], the largest global conservation organization, to implement the ecohomes scheme in England. In Slovakia (Central Europe), the drafting of a legislative proposal for an act on territorial and spatial planning has been initiated by the Ministry of Environment [18] with the ambition to push through permanent sustainability principles in territorial planning at the level of local authorities. The proposed housing development strategy is to come into force from 2020, and its focus on individual housing construction marks the start of a new housing culture that pursues the vision of healthy and civilized housing in a safe and harmonious green environment. The proposed development strategy for the future promises to offer selected locations in suburban areas for affordable prices for people living in cities [19].

According to Cholujová [10], the trend we witness nowadays is that people are going back from the impersonal and restrictive conditions of tower blocks to the more natural and relaxed conditions of family houses. Companies have substantially responded to this trend, meeting the demand by offering a wide range of solutions. Alongside the traditional and long-established construction materials—such as brick and concrete-companies are introducing modern, innovative, and viable construction alternatives. Among such alternatives are houses based on wood. Modern methods of construction (MMC) promote the idea and application of environmentally an energetically efficient constructions.

Construction of buildings and their operation is one of the main forms of consumption of material and energy resources, not just during the completion stage, but also during all periods of their existence (so-called construction lifecycle) [20-24]. According to Rajničová [25], a construction's lifecycle consists of quarrying, processing, production of components for building products and materials, material and product distribution, construction completion, use, maintenance, disposal, recycling or reuse [26-28]. In a construction's lifecycle, the following phases are key according to Tywoniak and Novák [29]: production of components for building products and materials, construction of buildings and their use with respect to ecological, economic and social aspects [30].

According to Schau et al. [31] the life-cycle assessment (LCA) of the environmental domain is largely used in the construction industry [32-35]. However, these authors add that the life-cycle costs (LCC) methodology is increasingly underestimated as an evaluation of construction projects [36-38].

The environmental assessment of the LCA has been around since the sixties of the last century [39]. Life-cycle cost assessment (LCC) is a newer methodology and is constantly evolving. The LCC is currently being evaluated as an important priority tool that is able to make the economics of sustainability more efficient in many areas [40,41].

Life-cycle assessment (LCA) is an analytical method of assessing the environmental impact of products, services, and technologies in all phases of a lifecycle. The LCA method analyses the environmental impact of all utilized products, from the stage of acquiring and processing input materials, through the stage of product manufacturing and its use, to the stage of its disposal, reuse, 
or recycling [35]. Environmental impact is assessed on the basis of assessing the environmental aspects of material and energy flows and their impact on the environment. The most frequently used LCA assessment parameters are embodied energy (EE), global warming potential (GWP), and acidification potential (AP), within specified boundaries [27].

Normally, standardized ISO standards are used for LCA assessment [42,43], but general standards are currently absent from the LCC for sustainability [44]. However, for the construction industry, ISO 15686-5 [45] is used to assess the costs of a building's lifecycle (Figure 1).

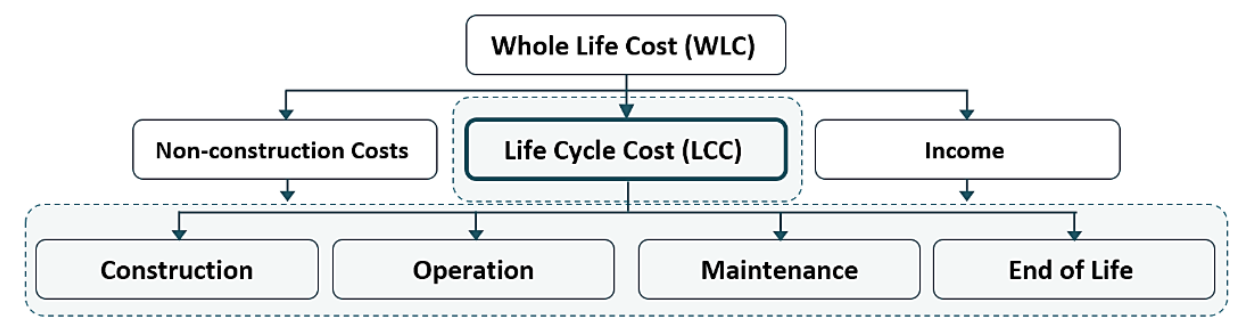

Figure 1. The basic structure of the life-cycle cost (LCC) evaluation in context with WLC [45].

The term whole life cost is defined by ISO 15686-5 [45] as "assessment expressed in monetary value taking into account all significant and relevant initial capital costs and future net costs and benefits, as defined in the agreed scope. The projected costs are those needed to achieve defined levels of performance, including reliability, safety and availability over the period of analysis".

The LCC methodology assesses life-cycle costs as "cost of an asset or its parts throughout its lifecycle, while fulfilling the performance requirements and life-cycle costing as the methodology for the assessment of these costs"; "methodology for systematic economic evaluation of life-cycle costs over a period of analysis, as defined in the agreed scope" [45-47].

The use of modern methods of construction (MMC) is a reaction to an increase in construction productivity, as the methods, according to Burwood and Jess [13] "provide efficient procedures (for both construction design and completion) that increase the volume of production, with a higher quality and less time required for obtaining them". The benefit of MMC is that they improve quality, reduce negative environmental impacts, and shorten construction times by making the building industry more efficient [48-50].

The interpretations of the term MMC involve different concepts in different countries. In Asia, they use the term 'industrialized building systems', Australia and the US use the term 'off-site construction methods' and the UK and Central Europe use the term 'modern methods of construction'. MMC methods are divided into 'off-site construction methods' and 'on-site construction methods'. MMC methods generally use traditional or innovative materials in combination with innovative workflows [11,51].

Modern wood-based construction methods are widely used in Central Europe [52]. In addition to the other advantages mentioned, wood-based MMCs are characterized by the so-called dry construction method, which allows construction to be carried out even in winter months [53-55]. Modern wood-based construction systems have excellent thermal and technical properties, contributing to the efficiency of use in terms of savings on heating [56,57]. A further advantage of these structures is the minimization of so-called wet processes during construction, thus not causing undesirable errors due to the built-in moisture in the structures [58-60], which ultimately accelerates the use of the building immediately after it is completed. The main benefit of these types of construction is the use of wood as a renewable raw material, whereby the construction of such types of construction is less environmentally damaging and contributes to sustainability [61].

However, although many benefits are associated with the use of MMC based on wood, the main barrier to their widespread growth in Central Europe is low awareness of these structures. On the 
other hand, in the Scandinavian countries, these buildings have been implemented effectively and contributed to a more sustainable way of living.

Implementation of sustainability must be presented in the context of the synergy of the basic components with each other $[7,62,63]$. Each component of sustainability ultimately impacts on another, and it is therefore necessary to respect these principles [64,65]. Based on a better understanding and deepening of knowledge in the area of economic sustainability, we have focused on this article to analyze the economic characteristics of construction, which, as mentioned above, have a direct impact on the social sphere and, ultimately, on environmental sustainability.

This contribution examines the environmental and economic impact of suburban housing clusters in terms of selected sustainability parameters. For our analysis of suburban housing clusters designed to serve as family houses, we chose, as our reference construction, an actual family house construction completed using a modern construction system based on wood from prefabricated sandwich panels. For the sake of comparing the impacts, we created an alternative model of a construction based on a traditional masonry construction system. The main objective of this contribution is to analyze selected variants of construction in terms of environmental and economic sustainability characteristics, as part of a broader assessment of permanent sustainability, by applying the life-cycle assessment (LCA) and life-cycle cost (LCC) methodologies within specified assessment boundaries. This contribution points towards the ways of applying the LCA and LCC assessment methodologies, such as in these decision-making processes: assessment and comparison in alternative investment strategies; determination of a project's viability; assessment and concepts of various reconstruction and maintenance methods; and choosing from a variety of construction materials and technologies, elements, and systems in the context of sustainability.

\section{Materials and Methods}

The subject of our study was an actual assembled construction from prefabricated sandwich panels based on wood and an alternative design of this construction built using a traditional masonry family house construction technology. The comparison of the benefits and limitations of the individual variants was in terms of the environmental and economic sustainability characteristics.

The reference house (Figures 2 and 3) is a concept consisting of a two-floor cubic structure overlapping a rectangular single-floor structure forming the base of the house. The concept is thoughtfully projected both in terms of internal layout and in terms of the materials used for the exterior. The interior space is dominated by a spacious entrance hall with vertical illumination through a roof window. Its ground floor bedrooms with en-suite bathrooms make the house suitable as a multi-generational home. The construction covers an area of $24 \times 15 \mathrm{~m}$ and the volume of the enclosed space is $1150 \mathrm{~m}^{3}$ [66]. The assessed variants differ mainly with respect to their material bases. The modern assembled structure variant from prefabricated sandwich panels consists of a wooden support system. The traditional structure variant consists of ceramic masonry elements with lintels and a ceiling plate from reinforced concrete. While both variants sit on foundation frames, the masonry variant has more massive foundations as the construction is significantly heavier. The roofing is the same in both cases. The variants were built according to comparable energy standards, so they had to be designed with different thickness of their respective external walls and with different thickness of heat insulation for their external walls. The thickness of the external wooden walls is $270 \mathrm{~mm}$, while in the masonry construction the thickness is $440 \mathrm{~mm}$. A contact insulation system is applied to the walls of both variants $100 \mathrm{~mm}$ layer on the panel wood construction and a $160 \mathrm{~mm}$ layer on the masonry construction. More detailed material composition of these variants is presented in Table 1. 


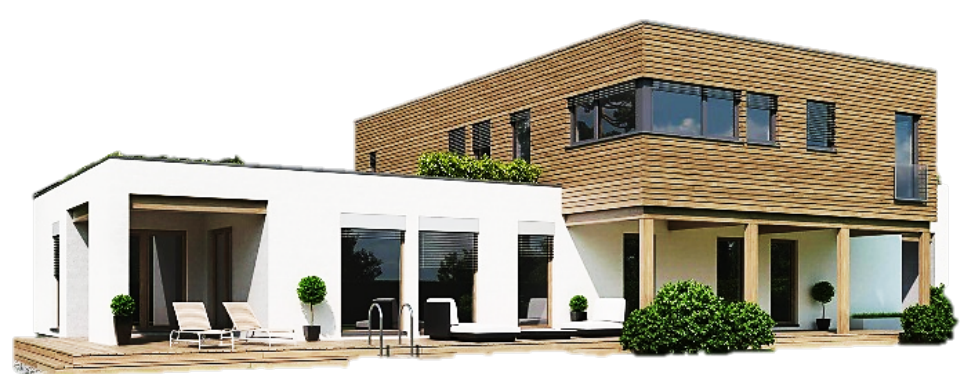

Figure 2. Reference house [66].
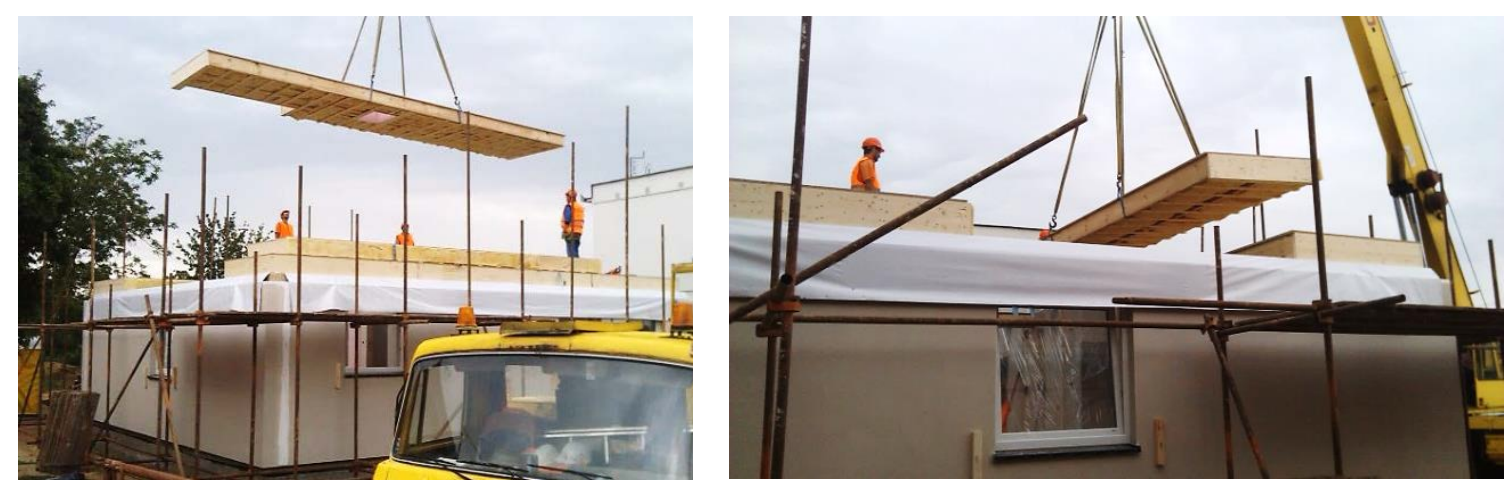

Figure 3. Construction of a prefabricated construction system based on wood.

Table 1. Detailed composition of wall, ceiling, and roof structures of construction variants.

\begin{tabular}{clll}
\hline & Concrete \\
reinforcement \\
waterproofing
\end{tabular}




\subsection{LCA Assessment Methodology}

The LCA method according to the EN 15978 [35] standard was applied to the assessment of environmental characteristics. The LCA analysis was used to assess the following indicators: embodied energy (EE), global warming potential (GWP), and acidification potential (AP), all within the boundaries of "Cradle to Gate".

The input values for the analysis of the environmental indicators of construction materials were from the IBO Austrian Institute for Healthy and Ecological Building (IBO Passivhaus-Bauteilkatalog). "The Austrian Institute for Healthy and Ecological Building continuously processes and updates its international database of construction materials use together with their environmental coefficients $\left(E E_{i}, E C O_{2 i}, E S O_{2 i}\right)$ required for an environmental parameters assessment (EE, GWP and AP)". The formulas for the calculation are presented below.

Embodied energy $(E E)$ was calculated based on the formula

$$
E E=\sum_{i=1}^{n} E E_{i} \times w_{i}[\mathrm{MJ}]
$$

note: $\left(E E_{i}=\right.$ coefficient of embodied energy for $i$-th material [MJ $\left.\cdot \mathrm{kg}^{-1}\right] ; w_{i}=$ weight of $i$-th material $\left.[\mathrm{kg}]\right)$.

Global warming potential (GWP) was calculated based on the formula

$$
G W P=\sum_{i=1}^{n} E \mathrm{CO}_{2_{i}} \times w_{i}[\mathrm{kgCO} \mathrm{kq}]
$$

note: $\left(E \mathrm{CO}_{2_{i}}=\right.$ coefficient of carbon dioxide equivalent for $i$-th material $\left[\mathrm{kgCO}_{2 \mathrm{eq}} \cdot \mathrm{kg}^{-1}\right] ; w_{i}=$ weight of $i$-th material $[\mathrm{kg}])$.

Acidification potential $(A P)$ was calculated based on the formula

$$
A P=\sum_{i=1}^{n} E S O_{2_{i}} \times w_{i}\left[\mathrm{kgSO}_{2 \mathrm{eq}}\right]
$$

note: $\left(\mathrm{ESO}_{2_{i}}=\right.$ coefficient of sulphur dioxide equivalent for $i$-th material $\left[\mathrm{kgSO}_{2 \mathrm{eq}} \cdot \mathrm{kg}^{-1}\right] ; w_{i}=$ weight of $i$-th material $[\mathrm{kg}])$.

$\mathrm{CO}_{2}$ emissions produced during the transport of construction materials and the construction's structural parts play an important role in the context of sustainability $[67,68]$. The environmental aspect of the assessment was therefore extended to include the impact of the transport of construction materials and products used in the construction of the assessed variants from production to the construction site. The impact of transport on the environment was assessed in terms of the $\mathrm{CO}_{2}$ emissions produced during transport. The formulas used in this analysis are presented below.

The number of journeys (NJ) was determined according to the formula

$$
N J=\sum_{\substack{i=1 \\ k=1}}^{l} \frac{w_{i}}{t c_{k}}[-]
$$

note: $\left(w_{i}=\right.$ weight of $i$-th material $[\mathrm{kg}] ; t c_{k}=$ transport capacity of $k$-th transport vehicle $\left.[\mathrm{kg}]\right)$.

$\mathrm{CO}_{2}$ emissions produced during transport were determined according to the formula

$$
E_{\mathrm{CO}_{2}}=\sum_{i=1}^{n} N J_{i} \times d_{i} \times \bar{x}_{\mathrm{CO}_{2_{k}}}[\mathrm{~kg}]
$$

note: $\left(N J_{i}=\right.$ number of journeys for $i$-th material $[-] ; d_{i}=$ transport distances for $i$-th material $[\mathrm{km}]$; $\bar{x}_{\mathrm{CO}_{2_{k}}}=$ average value of $\mathrm{CO}_{2}$ emissions for $k$-th transport vehicles $\left.\left[\mathrm{kg} \cdot \mathrm{km}^{-1}\right]\right)$.

\subsection{LCC Assessment Methodology}

The LCC method according to the ISO 15686-1 [69] and ISO 15686-5 [45] standards was applied to the assessment of economic sustainability characteristics. The LCC analysis was used to assess the 
costs associated with the assessed variants for the entire lifecycle of the constructions. The life-cycle time (LCT) methodology was created for the purposes of assessing time characteristics.

According to the ISO 15686-5 [45] standard, "to ensure accuracy in cost considerations, current (real) costs are recommended. Using real costs allows current known information to be used in an analysis of a process. For this analysis, a base date should be set in the recent past or near future. A recent or near future date is usually chosen because people are familiar with the current cost and the cost environment in which they live, work or think. A value in real cost is the monetary amount to be paid if the cost occurred at the base date, regardless of which point in time it actually occurs". That is why we have calculated the inflation without the impact of inflation, so we analyzed the present value.

According to the ISO 15686-5 [45] standard, it is also that "future inflation is highly uncertain. Those analyzing LCC should avoid making assumptions about the general rate of inflation whenever possible by using real costs. However, if it is necessary to use nominal costs assumptions made about discount rates (and underlying inflation rates) should be explicit and the sensitivity should be checked". Therefore, we have completed a review of the sensitivity for the $1 \%, 3 \%$, and $5 \%$ discount rates for long-term costs of use, maintenance, and disposal.

Assessing the economic parameters is an important part of monitoring the time needed for construction. For the analysis, the time schedules of construction were created using the software used in our conditions to evaluate construction in terms of the time of construction of MS Projects and Cenkros Plus (Formula (6)). Cenkros Plus software uses the CENEKON database (CENEKON is a national database of Slovak republic of the construction processes and materials with their cost and time parameters). For better clarity, partial processes are divided into the subcategories being evaluated (Table 2).

Table 2. Process map of construction variants.

\begin{tabular}{|c|c|c|}
\hline & Panel Wood Construction & Masonry Construction \\
\hline Foundations & $\begin{array}{ll}- & \text { surveying of construction site and objects } \\
- & \text { excavation for foundations } \\
\text { - } & \text { foundations (strip foundations and concret } \\
\text { - } & \text { waterproofing of foundations }\end{array}$ & e slab) \\
\hline $\begin{array}{l}\text { Vertical and } \\
\text { horizontal } \\
\text { structures }\end{array}$ & 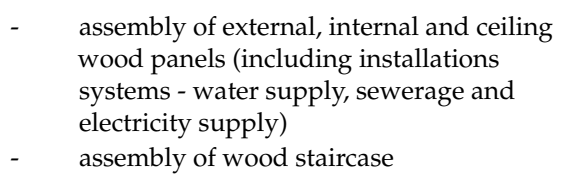 & $\begin{array}{ll}\text { - } & \text { construction of load-bearing walls } \\
\text { - } & \begin{array}{l}\text { construction of ceiling monolithic structure } \\
\text { (reinforces concrete ceiling slab) }\end{array} \\
\text { - } & \text { construction of partitioncon } \\
\text { - } & \text { struction of reinforced concrete stairway }\end{array}$ \\
\hline Roofing & \multicolumn{2}{|c|}{$\begin{array}{l}\text { assembly of wooden load-bearing structure } \\
\text { assembly of roofing layers (thermal insulation, waterproofing covering) } \\
\text { roofing }\end{array}$} \\
\hline $\begin{array}{l}\text { Surfacing and } \\
\text { completions }\end{array}$ & $\begin{array}{l}\text { - } \quad \begin{array}{l}\text { completion of windows and doors } \\
\text { - }\end{array} \\
\text { completion of floors, walls and } \\
\text { - } \quad \text { ceilings surfacing } \\
\text { - } \quad \text { completion of technical equipment }\end{array}$ & $\begin{array}{ll}\text { - } & \begin{array}{l}\text { construction of distribution systems } \\
\text { (water supply, sewerage and electricity supply) }\end{array} \\
\text { - } & \text { completion of windows and doors } \\
\text { - } & \text { completion of floors, walls and ceiling surfacing } \\
\text { - } & \text { completion of technical equipment } \\
\text { - } & \text { completion of external thermal insulation }\end{array}$ \\
\hline
\end{tabular}




$$
C T=\sum_{j=1}^{m} V_{j} \times t_{j}[\text { hours }]
$$

note: (CT-construction time; $V_{j}$-volume of $j$-th project items $\left[\mathrm{m}^{3}\right] ; t_{j}$-unit man-hour of $j$-th project items $\left[\right.$ EUR $\left.\left.\cdot \mathrm{m}^{-3}\right]\right)$.

For both evaluated variants, the real cost budgets needed to build complete buildings with Cenkros Plus software were compiled. According to Formula (7), the individual processes were evaluated in terms of cost.

$$
C C=\sum_{j=1}^{m} V_{j} \times c_{j}[\mathrm{EUR}]
$$

note: (CC—-construction costs; $V_{j}$-volume of $j$-th budget items $\left[\mathrm{m}^{3}\right] ; c_{j}$ - unit price of $j$-th budget items $\left.\left[\mathrm{EUR} \cdot \mathrm{m}^{-3}\right]\right)$.

From the comparison of the transport of the compared variants, Formulas (3) and (4) were used in the context of construction and demolition of buildings, in the context of LCC and LCT. The transport costs and transport time was calculated using Formulas (8) and (9). From the point of view of the transport, the transport distance of $20 \mathrm{~km}$ was considered for each of the assessed areas.

$$
T C=\sum_{j=1}^{m} V_{j} \times c_{j}[\mathrm{EUR}]
$$

note: $\left(V_{j}\right.$-volume of $j$-th budget items $\left[\mathrm{m}^{3}\right] ; c_{j}$ - unit price of $j$-th budget items [EUR. $\left.\left.\mathrm{m}^{-3}\right]\right)$.

$$
T T=\sum_{j=1}^{m} V_{j} \times t_{j}[\mathrm{EUR}]
$$

note: $\left(V_{j}\right.$-volume of $j$-th project items $\left[\mathrm{m}^{3}\right] ; t_{j}$ - unit man-hour of $j$-th project items [EUR. $\left.\left.\mathrm{m}^{-3}\right]\right)$.

From the point of view of the operating costs of panel wood construction, the real costs incurred during use in recent years were considered. In the case of the brickwork of the masonry construction, the same costs were considered, because the design of this variant was considered with the same energy standard as in the construction of panel wood construction. Costs for real estate and land taxes during the period under consideration were also included in operating costs.

Maintenance and repair costs are calculated on the basis of the standard set in our terms. This means that during use, a certain amount of money is accumulated during the years of use in the so-called repair fund. The repairers fund is used to cover the maintenance, repair, and reconstruction costs of the future. In analysis, the use of buildings was considered for 50 years.

\section{Results}

The following parts of the contribution present a comparative analysis of the selected construction variants using the preferred methodologies and the set assessment boundaries in terms of the environmental and economic sustainability characteristics.

The analysis of the construction variants in terms of embodied energy (EE) shows significant differences in favor of the modern construction system based on wood, where a $54 \%$ reduction in EE was observed compared to the traditional masonry system (Figure 4). The observed deviations are particularly apparent in the foundations and in the overground construction sections. The deviations in the case of the foundations exist due to the masonry variant's more massive foundations designed to have a greater bearing capacity. The masonry construction's overground sections were significantly heavier compared to the variant based on wood. As for the overground sections, these differences can be attributed to the fact that the materials (bricks, concrete, plaster, reinforcement, etc.) show significantly higher values of this assessed EE indicator. 


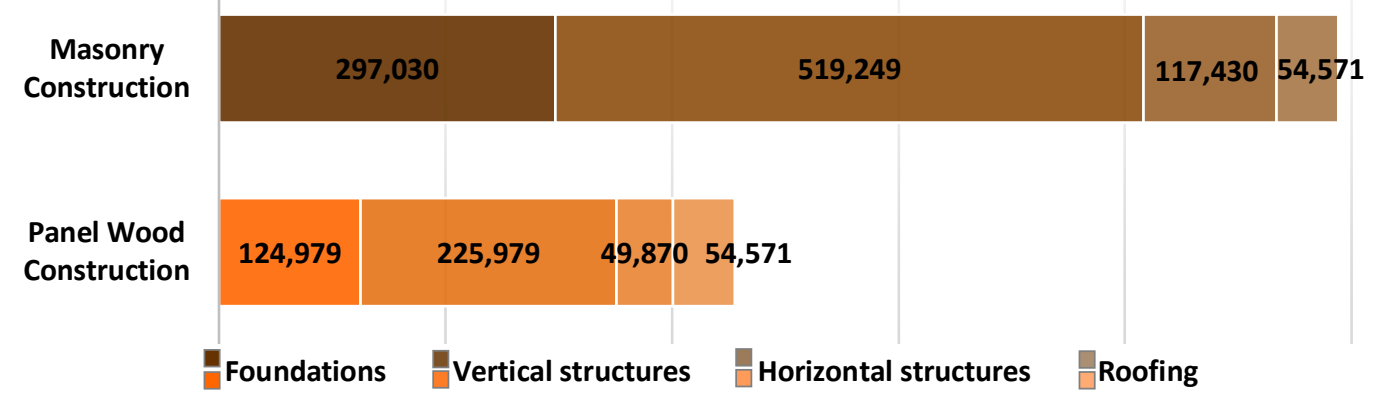

Figure 4. Analysis of embodied energy (EE) [MU].

Even more significant deviations between the compared construction variants were observed in the case of global warming potential (GWP) (Figure 5). In contrast with the traditional masonry variant, an almost 155 percent reduction in GWP in favor of the modern construction system based on wood was found. As in the cased of the EE parameter, it is the foundations and the overground sections that accounted for the deviations. This extreme difference can also be attributed to the fact that wood shows excellent values of this assessed indicator compared to other construction materials. As wood absorbs significant amounts of $\mathrm{CO}_{2}$ during growth, its values for this parameter are negative.

As for the comparison of the construction variants in terms of acidification potential (AP), a $36 \%$ reduction in AP in favor of the variant based on wood was observed compared to the variant based on masonry elements and reinforced concrete structural parts (Figure 6). This difference was not as significant as in the case of the previous assessed indicators. This can also be attributed to the fact that wood does not show such significant values of this parameter, as it stops absorbing harmful emissions after it is extracted. However, it still has better environmental parameters than traditional construction materials such as ceramic bricks, concrete, and reinforced concrete.

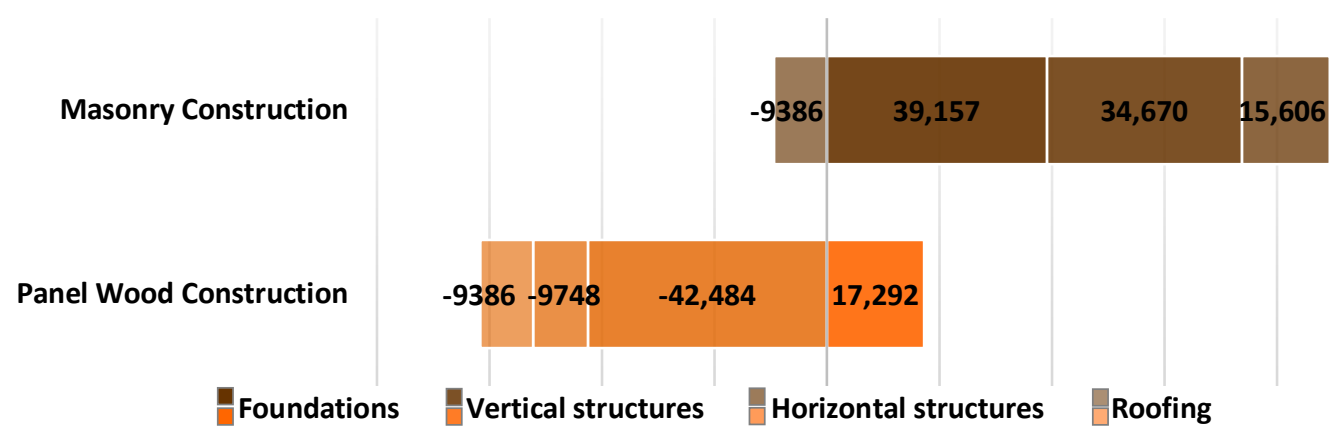

Figure 5. Analysis of global warming potential (GWP) $\left[\mathrm{kgCO}_{2} \mathrm{eq}\right]$.

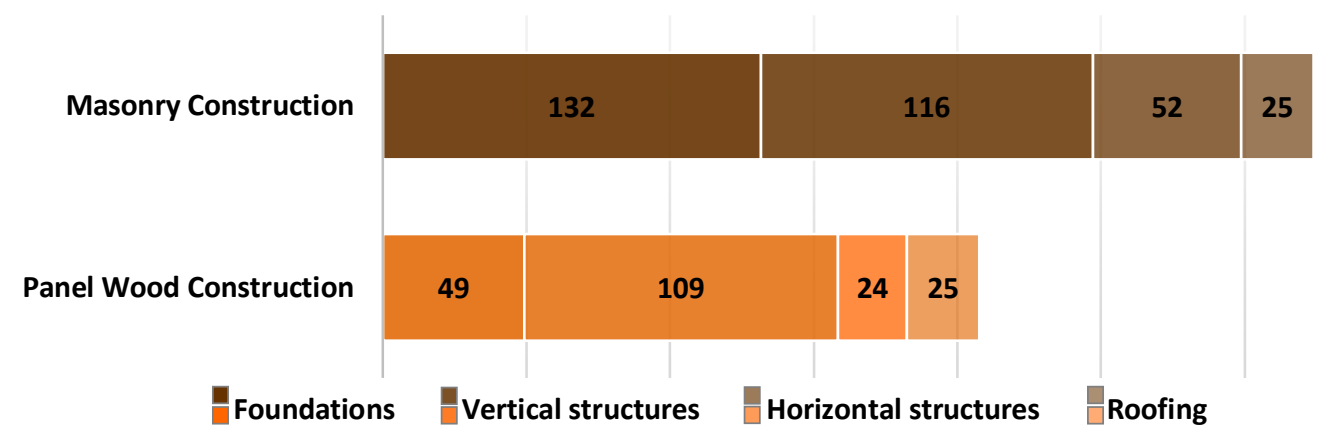

Figure 6. Analysis of acidification potential (AP) $\left[\mathrm{kgSO}_{2} \mathrm{eq}\right]$. 
The analysis of $\mathrm{CO}_{2}$ emissions produced during the transport of materials and structural parts required for constructing the selected variants showed clear superiority of the construction system based on wood over the heavy construction based on masonry elements. Substantial differences were found when monitoring the number of transport journeys, where a $63 \%$ and a $60 \%$ difference in favor of the significantly lighter construction based on wood was observed. If we transported all the material required for the variant based on wood over a distance of $100 \mathrm{~km}$, the emissions would be equivalent to what the masonry variant would produce over a distance of $20 \mathrm{~km}$ (Table 3, Figure 7).

Table 3. Calculation of the $\mathrm{CO}_{2}$ emissions generated during the transport of materials and products.

\begin{tabular}{|c|c|c|c|c|c|c|c|c|}
\hline & \multicolumn{2}{|c|}{ Transported Quantities (t) } & \multicolumn{2}{|c|}{ Number of Rides } & \multirow{2}{*}{$\begin{array}{l}\text { Transport } \\
\text { Distance } \\
(\mathbf{k m})\end{array}$} & \multirow{2}{*}{$\begin{array}{c}\text { Average Emissions } \\
\mathrm{CO}_{2} \text { of Vehiclesk } \\
\mathrm{g} / \mathrm{km}\end{array}$} & \multicolumn{2}{|c|}{$\begin{array}{c}\text { Emissions of } \mathrm{CO}_{2} \\
(\mathrm{~kg})\end{array}$} \\
\hline & PWC & MC & PWC & MC & & & PWC & MC \\
\hline Concrete & $\begin{array}{c}147.6 \\
\left(61.5 \mathrm{~m}^{3}\right)\end{array}$ & $\begin{array}{c}354.24 \\
\left(147.6 \mathrm{~m}^{3}\right)\end{array}$ & 11 & 25 & 20 & \multirow{6}{*}{0.8} & 176 & 400 \\
\hline Reinforcement & 2.46 & 12 & 1 & 1 & 20 & & 16 & 16 \\
\hline Formwork system & - & $\begin{array}{c}16.23 \\
\left(202.9 \mathrm{~m}^{2}\right)\end{array}$ & 0 & 1 & 20 & & 0 & 16 \\
\hline $\begin{array}{l}\text { Panels of wood } \\
\text { construction }\end{array}$ & 46.12 & - & 2 & 0 & $\begin{array}{c}20 \\
(50,100) *\end{array}$ & & $\begin{array}{c}32 \\
(80,160) *\end{array}$ & 0 \\
\hline Masonry material & - & 173.4 & 0 & 9 & 20 & & 0 & 144 \\
\hline Timber & 8.61 & 8.61 & 1 & 1 & 20 & & 16 & 16 \\
\hline Sum & 204.79 & 564.48 & 14 & 37 & & & $\begin{array}{c}240 \\
(288,368) *\end{array}$ & 592 \\
\hline
\end{tabular}

note: PWC-Panel Wood Construction, MC-Masonry Construction, ${ }^{*}$ for transport distance alternatives of 50 and $100 \mathrm{~km}$.

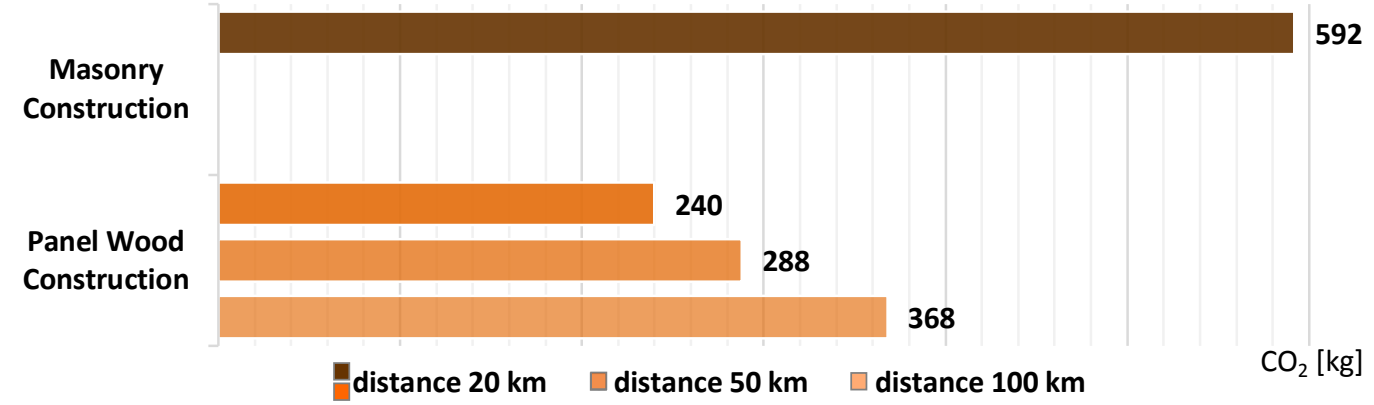

Figure 7. Analysis of $\mathrm{CO}_{2}$ emissions produced by the variants.

The present value of costs is shown in Table 4 in the breakdown of the basic stages of the lifecycle of the construction. When the analysis was considered the duration of use of 50 years.

Applying the LCC assessment methodology allowed us to compare the variants in terms of the costs involved throughout the constructions' lifecycles. The most significant difference in costs in favor of the variant based on wood was observed for the completion phase $(15 \%)$ and the end-of-life phase (almost 60\%). This significant difference in the end-of-life phase is due to the fact that demolition, transport, and disposal of the construction based on masonry and reinforced concrete is much more demanding, whether in terms of man hours or costs. As for operation and maintenance, we did not observe a difference, as we simulated the same conditions of use and maintenance costs-the selected variants were defined so as to be comparable in terms of thermal-technological characteristics. The thermal-technical parameters of the construction systems play an important role when it comes to later use of the construction and operational costs. 
Table 4. Life-cycle cost analysis—the current value of the compared variants.

\begin{tabular}{|c|c|c|c|c|c|}
\hline & & Masonry Construction & & Panel Wood Construction & \\
\hline $\begin{array}{l}\text { Lifecycle } \\
\text { Phase }\end{array}$ & Phase & & $\begin{array}{l}\text { Costs } \\
\text { (EUR) }\end{array}$ & & $\begin{array}{l}\text { Costs } \\
\text { (EUR) }\end{array}$ \\
\hline \multirow{3}{*}{ Construction } & Costs of building design & & 2994 & & 2371 \\
\hline & $\begin{array}{l}\text { Costs for the production of } \\
\text { materials and components }\end{array}$ & 149,205 & & 118,584 & \\
\hline & $\begin{array}{l}\text { Transport costs of materials } \\
\text { and components * }\end{array}$ & $\begin{array}{l}2361 \text { (transport-distance } 20 \mathrm{~km} \text { ) } \\
2415 \text { (fixed costs) }\end{array}$ & 4776 & $\begin{array}{l}984 \text { (transport-distance } 20 \mathrm{~km} \text { ) } \\
2004 \text { (fixed costs) }\end{array}$ & 2988 \\
\hline Operation & Operating costs & $\begin{array}{l}680 \text { (average annual cost of heating, } \\
\text { water heating and cooling) } \\
192 \text { (average annual cost of lighting } \\
\text { and electrical equipment) } \\
72 \text { (average annual cost of property } \\
\text { tax and land) }\end{array}$ & 47,200 & $\begin{array}{l}680 \text { (average annual cost of heating, } \\
\text { water heating and cooling) } \\
192 \text { (average annual cost of lighting } \\
\text { and electrical equipment) } \\
72 \text { (average annual cost of property } \\
\text { tax and land) }\end{array}$ & 47,200 \\
\hline Maintenance & $\begin{array}{l}\text { Maintenance and } \\
\text { repair costs *** }\end{array}$ & $\begin{array}{l}\mathbf{6 1 1} \text { (average annual } \\
\text { cost—repairs fund) }\end{array}$ & 30,550 & $\begin{array}{l}518.4 \text { (average annual } \\
\text { cost-repairs fund) }\end{array}$ & 30,550 \\
\hline \multirow[t]{2}{*}{ End-of-Life } & $\begin{array}{l}\text { Costs of demolition } \\
\text { and disposal }\end{array}$ & $\begin{array}{l}5991 \text { (demolition) } \\
\text { 10,516 (transport and disposal) }\end{array}$ & 16,507 & $\begin{array}{l}3012 \text { (demolition) } \\
3685 \text { (transport and disposal) }\end{array}$ & 6697 \\
\hline & & Sum & 335,114 & Sum & 281,840 \\
\hline
\end{tabular}

By creating the methodology for assessing the so-called LCT, we could compare the proposed variants in terms of time characteristics-a much-demanded parameter when acquiring constructions (Table 5). The completion phase is the most interesting, as the quicker it is to complete a construction project, the more efficiently we can assess the costs. As for completion, we observed a 48 percent difference between the compared variants in favor of the system based on prefabricated panels based on wood as opposed to the traditional masonry system. A similar $45 \%$ difference in favor of the variant based on wood was observed in the case of the demolition and disposal of the construction after the end of its lifecycle.

Table 5. Lifecycle time analysis of comparison variants.

\begin{tabular}{|c|c|c|c|c|c|}
\hline & & Masonry Construction & & Panel Wood Construction & \\
\hline Lifecycle Phase & & Time (Weeks) & & Time (Weeks) & \\
\hline \multirow[b]{3}{*}{ Construction } & Time for building design & & 4 & & 4 \\
\hline & $\begin{array}{l}\text { Time of transport of } \\
\text { materials and components * }\end{array}$ & Calculated at construction time & & Calculated at construction time & \\
\hline & Construction time $* *$ & $\begin{array}{l}5 \text { weeks (foundations) } \\
8.5 \text { weeks (vertical and } \\
\text { horizontal structures) } \\
1.5 \text { weeks (roofing) } \\
13.5 \text { weeks (surfacing and completions) }\end{array}$ & 28.5 & $\begin{array}{l}5 \text { weeks (foundations) } \\
1.5 \text { weeks (vertical and } \\
\text { horizontal structures) } \\
1.5 \text { weeks (roofing) } \\
7 \text { weeks (surfacing and completions) }\end{array}$ & 15 \\
\hline Operation & Duration of use & 50 years (duration of use in years) & & 50 years (duration of use in years) & \\
\hline Maintenance & Maintenance and repair time & 50 years (duration of use in years) & & 50 years (duration of use in years) & \\
\hline \multirow[t]{2}{*}{ End-of-Life } & $\begin{array}{l}\text { Time for demolition } \\
\text { and disposal }\end{array}$ & $\begin{array}{l}\mathbf{6} \text { weeks (demolition) } \\
5 \text { weeks (transport and disposal) }\end{array}$ & 11 & $\begin{array}{l}2.5 \text { weeks (demolition) } \\
2.5 \text { weeks (transport and disposal) }\end{array}$ & 5 \\
\hline & & Sum (except for the period of use) & 43.5 & Sum (except for the period of use) & 24 \\
\hline
\end{tabular}

Note: ${ }^{*}$-from production to building site, ${ }^{* *}$ —materials, labor, transport.

The comparison of the costs and time parameters of the assessed variants divided into basic lifecycle stages are shown in Figure 8. 


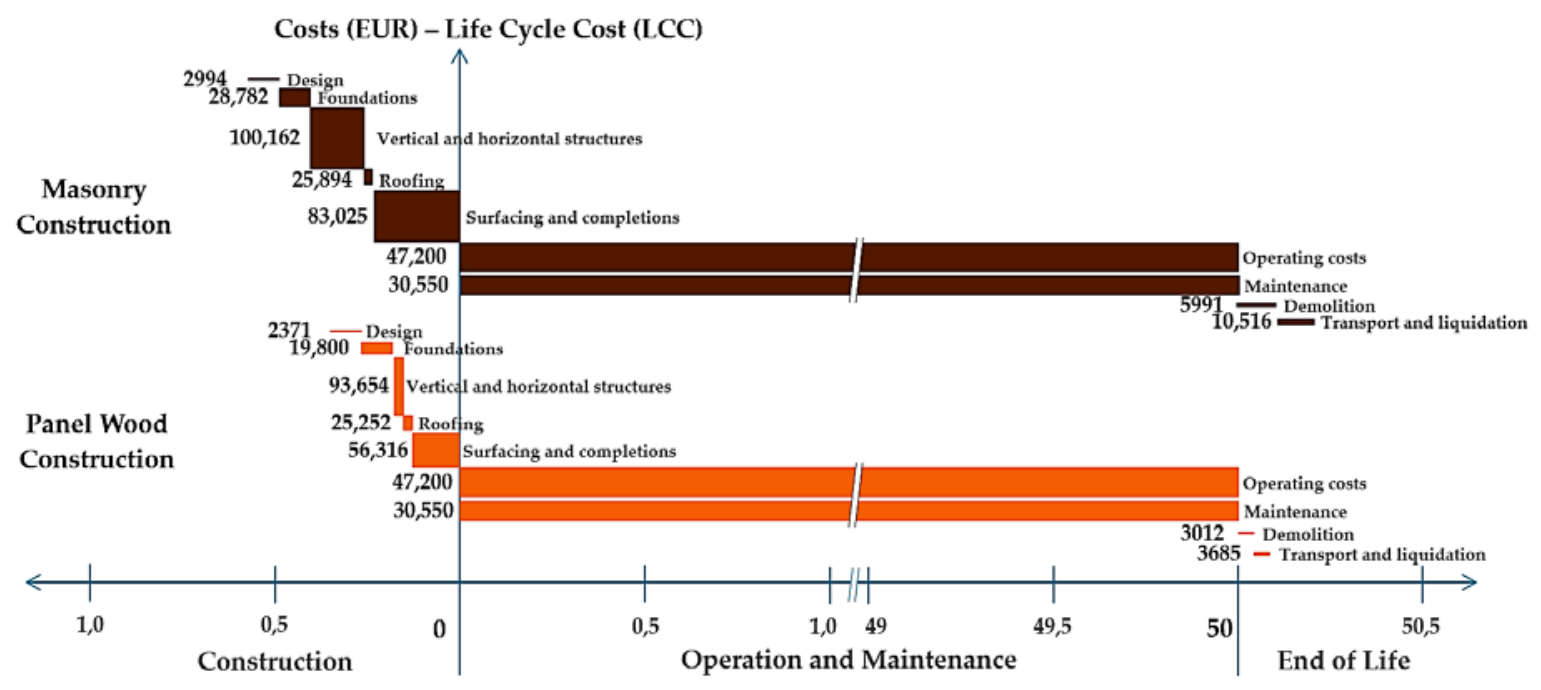

Time (years) - Life Cycle Time (LCT)

Figure 8. Analysis of the current LCC and LCT values of compared construction systems.

Since the discount rate is not accurately determined, a sensitivity analysis was performed and three discount rates at $1 \%, 3 \%$, and $5 \%$ were selected for discounting. The present value (initial value) of the costs influenced by inflation and the discounted values are shown in Tables 6 and 7 .

Table 6. Sensitivity analysis with changing discount rate-masonry construction.

\begin{tabular}{|c|c|c|c|c|c|c|c|c|}
\hline $\begin{array}{c}\text { Lifecycle } \\
\text { Phase }\end{array}$ & $\begin{array}{l}\text { Year in which } \\
\text { Cost Occurs } \\
\text { (Year) }\end{array}$ & $\begin{array}{c}\text { Expected } \\
\text { Yearly Cost } \\
\text { (EUR) }\end{array}$ & $\begin{array}{c}\text { Discount } \\
\text { Factors * } \\
\text { for } 1 \%\end{array}$ & NPV 1\% & $\begin{array}{c}\text { Discount } \\
\text { Factors * } \\
\text { for 3\% }\end{array}$ & NPV 3\% & $\begin{array}{l}\text { Discount } \\
\text { Factors * } \\
\text { for } 5 \%\end{array}$ & NPV 5\% \\
\hline \multirow{6}{*}{$\begin{array}{l}\text { Operation } \\
\text { and } \\
\text { Maintenance }\end{array}$} & 1 & 1555 & 0.990 & 1539 & 0.97 & 1508 & 0.95 & 1477 \\
\hline & 10 & 13,995 & 0.905 & $12,665.4$ & 0.74 & $10,356.3$ & 0.61 & 8536.9 \\
\hline & 20 & 15,550 & 0.820 & 12,751 & 0.55 & 8552 & 0.38 & 5909 \\
\hline & 30 & 15,550 & 0.74 & 11,507 & 0.41 & 6375.5 & 0.23 & 3576.5 \\
\hline & 40 & 15,550 & 0.67 & $10,418.5$ & 0.31 & 4820.5 & 0.14 & 2177 \\
\hline & 49 & 15,550 & 0.61 & 9485.5 & 0.23 & 3576.5 & 0.09 & 1399.5 \\
\hline \multirow[t]{2}{*}{ End-of-Life } & 50 (Demolition) & 16,507 & 0.61 & $10,069.2$ & 0.23 & 3796.6 & 0.09 & 1485.6 \\
\hline & Sum & 94,257 & & 68,436 & & $38,986.2$ & & $24,561.7$ \\
\hline
\end{tabular}

Note: NPV—Net present values, ${ }^{*}$-Discount factors by ISO 15686-5 [45].

Table 7. Sensitivity analysis with changing discount rate-panel wood construction.

\begin{tabular}{|c|c|c|c|c|c|c|c|c|}
\hline $\begin{array}{c}\text { Lifecycle } \\
\text { Phase }\end{array}$ & $\begin{array}{l}\text { Year in which } \\
\text { Cost Occurs } \\
\text { (Year) }\end{array}$ & $\begin{array}{l}\text { Expected } \\
\text { Yearly Cost } \\
\text { (EUR) }\end{array}$ & $\begin{array}{l}\text { Discount } \\
\text { Factors * } \\
\text { for } 1 \%\end{array}$ & NPV 1\% & $\begin{array}{l}\text { Discount } \\
\text { Factors * } \\
\text { for 3\% }\end{array}$ & NPV 3\% & $\begin{array}{c}\text { Discount } \\
\text { Factors * } \\
\text { for } 5 \%\end{array}$ & NPV 5\% \\
\hline \multirow{6}{*}{$\begin{array}{l}\text { Operation } \\
\text { and } \\
\text { Maintenance }\end{array}$} & 1 & 1555 & 0.990 & 1539 & 0.97 & 1508 & 0.95 & 1477.2 \\
\hline & 10 & 13,995 & 0.905 & 12,665 & 0.74 & 10,356 & 0.61 & 8536.9 \\
\hline & 20 & 15,550 & 0.820 & 12,751 & 0.55 & 8552.5 & 0.38 & 5909 \\
\hline & 30 & 15,550 & 0.74 & 11507 & 0.41 & 6375.5 & 0.23 & 3576.5 \\
\hline & 40 & 15,550 & 0.67 & $10,418.5$ & 0.31 & 4820.5 & 0.14 & 2177 \\
\hline & 49 & 15,550 & 0.61 & 9485.5 & 0.23 & 3576.5 & 0.09 & 1399.5 \\
\hline \multirow[t]{2}{*}{ End-of-Life } & 50 (Demolition) & 6697 & 0.61 & 4085.17 & 0.23 & 1540.3 & 0.09 & 602.7 \\
\hline & Sum & 84,447 & & $62,451.9$ & & $36,729.9$ & & $23,678.8$ \\
\hline
\end{tabular}

Note: NPV—Net present values, *—Discount factors by ISO 15686-5 [45].

Table 8 shows the change and the ratio of the total amount of the present value and the total cost of completion, repair or disposal of the construction due to the change in discount rates for the 50-year period. These tables are followed by Figure 9, which shows the development of lifecycle cost of the variants examined. 
Table 8. Ratio of the realization costs and costs of use and disposal at the discount rate.

\begin{tabular}{cccccccc}
\hline & & \multicolumn{3}{c}{ Masonry Construction } & \multicolumn{2}{c}{ Panel Wood Construction } \\
\hline NPV & & Construction & $\begin{array}{c}\text { Operation, Maintenance } \\
\text { and End-of-Life }\end{array}$ & Sum & Construction & $\begin{array}{c}\text { Operation, Maintenance } \\
\text { and End-of-Life }\end{array}$ & Sum \\
\hline $\mathbf{1 \%}$ & $\begin{array}{c}\text { Cost ratio } \\
\text { (EUR) }\end{array}$ & 240,857 & 68,436 & 309,293 & 197,393 & 62,451 & 259,844 \\
\hline $\begin{array}{c}\text { Percentage } \\
\text { ratio (\%) }\end{array}$ & 77.8 & 22.2 & 100 & 75.5 & 24.5 & 100 \\
\hline $\mathbf{3 \%}$ & $\begin{array}{c}\text { Cost ratio } \\
\text { (EUR) }\end{array}$ & 240,857 & 38,986 & 279,843 & 197,393 & 36,729 & 234,122 \\
\hline $\mathbf{5 \%}$ & $\begin{array}{c}\text { Percentage } \\
\text { ratio (\%) }\end{array}$ & 85.9 & 14.1 & 100 & 84.3 & 15.7 & 100 \\
\hline $\begin{array}{c}\text { Cost ratio } \\
\text { (EUR) }\end{array}$ & 240,857 & 24,561 & 265,418 & 197,393 & 23,678 & 221,071 \\
\hline $\begin{array}{c}\text { Percentage } \\
\text { ratio (\%) }\end{array}$ & 90.7 & 9.3 & 100 & 89.5 & 10.5 & 100 \\
\hline
\end{tabular}

Note: NPV—Net present values.

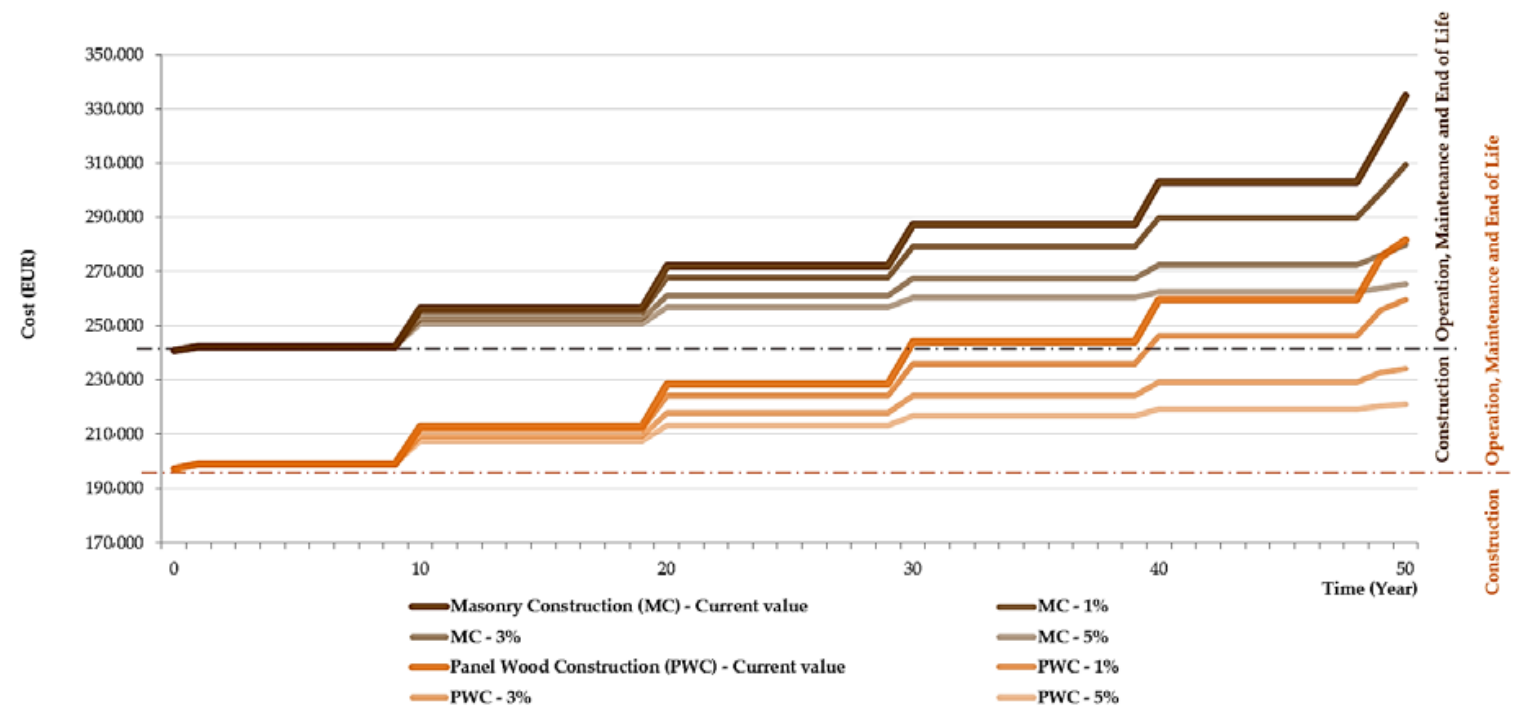

Figure 9. LCC development at current value and changing discount rates.

It is clear from Tables 6-8 that the time value of finance (the discounted rate used) fundamentally alters the ratio between completion costs and the costs of use, maintenance, and disposal. The lower the discount rate, the more it emphasizes the importance of the cost of use related to the technical parameters of building components and structures.

\section{Discussion}

Gustavsson and Sathre [70], similarly to ourselves, have been dealing with the comparison of wood-based buildings with buildings based on classical building materials such as concrete. The above-mentioned authors focused in particular on the comparison of building materials compared to the production of $\mathrm{CO}_{2}$ within selected phases of the building's lifecycle. Based on their research, these authors also point out that the use of wood in construction contributes to a significant reduction in $\mathrm{CO}_{2}$ production and a reduction in the use of fossil fuels needed to produce building materials and structural elements. Bhochhibhoya et al. [71] conducted a study similar to ours, the environmental and economic characteristics of the comparative variants of building construction systems. The above-mentioned authors have found that the use of local building materials whose production is not energy-intensive is far more environmentally beneficial than materials whose production pollutes environmentally and draws a lot of resources. Also, these authors point out 
that, from the point of view of economic benefits, materials that are local are more suitable. We also found similar findings in our work where we also analyzed the transport of building materials and found that if we do not use local materials and we need to import materials and building components from large distances, the overall project will not be as cost-effective and environmentally beneficial. Further consensus with these authors can be observed when deciding that the walls of the building construction systems have a significant impact on the overall environmental and economic footprint of the building in terms of the materials used. Santi et al. [72] also studied the environmental effects of the production of the wooden construction system and the traditional masonry construction system. These authors have arrived at similar findings to us, from which it follows that the constructional system is considerably more beneficial than the traditional construction system in terms of the evaluated parameters. In addition, these authors analyzed more environmental indicators than we were able to observe the additional benefits of a wood-based construction system. In addition, these authors analyzed more environmental indicators than we did in our work, through which other benefits of the wood-based construction system could be observed. Ximenes and Grant [73] were concerned with the application of LCA in construction industry. These authors concluded that negative impact on the environment in terms of sustainability can be reduced by the use of materials and construction parts based on wood, which could not be said of the use of traditional construction materials. These authors' conclusions agree with our findings from our comparison analysis. Of course, we are also of the view that we cannot dispense with traditional materials altogether, and much more efficient sustainability solutions can be achieved by combining the positive properties of ecological and traditional materials. Silvestre et al. [74] analyzed the economic and environmental aspect of various material and construction variants in the construction industry. Similarly to our work, these authors were concerned with assessing the above sustainability indicators in terms of the basic phases of a product's lifecycle. Similarly to our work, these authors concluded that better and more sustainable solutions could be achieved by combining materials according to cost effectiveness and environmental impact. These authors also say that the LCA and LCC methodologies are suitable tools for such assessments. An analysis of the environmental and economic impacts of the use of traditional building materials on building construction compared to more environmentally beneficial materials was dealt with by Morel et al. [75]. The above-mentioned authors, among other findings, state, like us, that the use of wood for construction has many benefits, both in terms of environmental impacts and in terms of acceleration and efficiency of the construction process. In his research, Blengini and Di Carlo [76] dealt with the analysis of building materials used to build buildings in terms of environmental impacts, taking into account the lifecycle. These authors have concluded that renewable materials such as wood contribute to the overall reduction of the negative environmental footprint of the resulting construction. As a result, when compared to traditional brick-built structures with wood-based structures, traditional masonry structures have a far more negative impact on the environment than buildings where renewable materials (wood, natural wool, etc.) are used. Pajchrowski et al. [77] is similar to what we were dealing with by comparing different material options for building home. Just as we in our study took into account the environmental characteristics of the compared variants. The conclusions of their research show a clear benefit of wood-based construction compared to buildings based on classical building materials (conventional masonry materials, concrete, etc.) within the considered assessment boundaries. Analysis of the material base of residential buildings was dealt with by Upton et al. [78]. Among other findings, these authors point out that wood-based buildings are much more environmentally and economically more suitable than conventional masonry and concrete building structures. These findings are supported by Almusaed and Almssad [79]. Even the work of these authors has shown other beneficial benefits of wood-based construction. Similar findings to us as far as the assessment of environmental indicators is concerned in their analyses by Glasare and Haglund [80]. The aforementioned authors compared different varieties of wood-based buildings and classical brick and concrete structures. Based on the findings, these authors state that the environmental benefits of wood-based buildings are indisputable compared 
to masonry structures. In addition, wood-based buildings also provide economic benefits in terms of shortening the construction period and reducing the amount of money spent, with which our work coincides.

Russell-Smith and Lepech [81] also applied the methodology of environmental and economic assessments within a product's lifecycle. Similarly to our work, these authors say that applying an assessment method that considers a product's lifecycle is a suitable tool for selecting and assessing different variants in terms of possible future time and cost saving, and environmental impact. From the point of view of applying the evaluation of the LCC methodology, the construction industry has enormous potential [31,82]. Goldstein and Eriksson [82] have examined the LCC methodology in terms of their application in public procurement as well as in the procurement of projects in construction through private entities. The aforementioned authors also examined the impact of LCC's assessment on measuring the economic benefits of environmentally-designed variants in decision-making processes. On the basis of their analyses, they concluded that the application of the LCC methodology may allow, in the initial phase, decisions that ultimately affect the overall profitability of the project. They also add, as one of the remarks, that the LCC analysis is sensitive to its applications in different countries, because each country has other specifics in particular in the field of building use. This specificity is ultimately reflected in the resulting portions, and therefore it is always necessary to specify the region in which the analysis is made and what boundary conditions are used in the calculation. In the field of construction, Afshari et al. [83] applied the life-cycle cost to evaluate different design alternatives. Among other findings, the LCC assessment tool is an important decision-making element in the construction industry. These conclusions are consistent with our findings on the basis of analyzes. We also point to the importance not only of LCC but also of LCT as another important element in decision making not only in construction. Toosi et al. [84] applied the LCC analysis into their construction research. In their work, they analyzed various LCC alternatives, resulting in a better understanding of the costs associated with each stage of the lifecycle. They have found that maintenance costs are a significant element in the cost lifecycle. We also support this claim because we have also found that maintenance costs play a significant role within the analyzed lifecycle stages. The authors also add that LCC analysis is an appropriate and effective tool for making blueprints between different variants and what we coincide with. We claim that the appropriate interpretation and use of LCCs can save costs in the future in important lifecycle stages. Alam and Singh [85] in his work analyzed, the economic characteristics of an office building project which was designed by means of vacuum insulation panels during its use. The LCC methodology applied by these authors involved the impact of various factors influencing the volatility of financial ties, such as heating efficiency, return on investment, and fluctuations in prices over the period under review. As a result of their analysis, it was determined that through the implementation of the LCC methodology it is possible to model the options that are able to make the future investment more efficient and increase its return before selecting a particular solution. The authors state in their research that using LCCs addresses the need for a lifecycle cost analysis as an important tool in the future for the decision-makers of different building project. Dwaikata and Ali [86] also applied the LCC assessment as an important decision-making factor in their study. Their research demonstrates how to conduct a life-cycle cost analysis for green buildings. They also found that the energy cost constitutes a weight of $48 \%$ of the total life-cycle budget of the green building. This finding is also consistent with our research, where we have similarly found that energy costs for use are a significant factor in cost-lifecycle stages. Marszal and Heiselberg [87] applied the LCC methodology into the multi-family Net ZEB. The above-mentioned authors evaluated several alternative designs in the LCC context. Just as we report that the LCC rating is of great importance in the future in terms of efficient spending of financial resources. Carter and Keeler [88] used the LCC methodology in their research for a better economic evaluation of the financial resources expended on different variants of green roofs. Through their analysis, they compared green roofs with streams based on common materials that are not environmentally beneficial. According to these authors, the lifecycle analysis of the proposed options can lead to better choices not only in terms of economic 
savings but also environmental benefits through the application of other evaluation tools from other aspects. The research findings of these authors have consistently highlighted the need to analyze the components of LCC in terms of future benefits, but also as an effective decision-making tool. Hasan [89] applied the LCC methodology to evaluate the optimization of the costs incurred during the lifecycle of the optimal insulation thickness, taking into account the function and the heat resistance of the walls. The study of these authors also proves that evaluating projects in construction through LCC is an effective tool for future cost savings. Schade [90] applied the LCC methodology within the construction industry. Based on his research, he states that in the construction industry, investors are often influenced by choosing the cheapest options, either in terms of a material solution or a design solution, which may not be the right thing to do. Based on the cost analysis in the context of the design lifecycle, we can see that if we choose the cheapest variant in the initial phase, it may increase costs during its use or operation. Therefore, it is advisable to process LCC analysis prior to acquiring any system or building unit, taking into account different options, thus improving the management of the funds in the future. This conclusion also agrees with this conclusion, especially that by evaluating several variants from the LCC perspective, it is possible to save future costs in terms of preferred life-cycle phases.

Based on our findings and analyses, when compared to the examined works, we can state that a construction's Life-cycle is a very long process, which includes several phases of the pre-investment phase, during which a project completion method is decided, through the completion and operation stage, to the end of its lifecycle and disposal. It is very difficult to determine all these costs and environmental impact. This is where the LCC and LCA methods prove useful. These methods allow us to include in the calculation the cost of acquisition, use and disposal at the end of a construction's lifecycle, as well as the environmental impact of the construction materials in terms of sustainability. The analysis of the studied variants based on different materials and constructions showed the benefits of the modern assembled construction based on wood in contrast with the traditional masonry construction method in terms of efficient use of resources in the context of sustainability. So the application of modern construction solutions based on wood promises to become an efficient and sustainable housing alternative, in line with the new philosophy of increasingly expanding sustainable suburban clusters.

\section{Conclusions}

Keeping in mind the current need for sustainable efficient housing in cities and their parts designed to serve as family houses, this article analyzed the traditional construction method as opposed to the modern construction method, which is becoming more and more common in Central Europe. Further, this article examined the application of the methodologies for assessing the environmental and economic sustainability indicators. The LCA and LCC methods were applied in order to assess the construction system variant based on wood and the traditional system based on masonry by means of a case study. The presented LCA and LCC analysis revealed the ways of reducing environmental impact and costs in favor of the modern construction based on wood within the selected lifecycle phases. This case study also introduced and examined the LCT assessment method, directly associated with the LCC method, and ultimately with the LCA method, which is why it is also important to analyze the latter. The LCT assessment also showed the benefits of the modern construction based on wood, particularly in the completion phase. Future operation costs are not a matter of a single event, they are gradually generated over a long period of time, these costs were reduced to their current amount. These costs were then compared with the completion costs, which confirmed the assumption that future operation costs in the case of the completed alternatives should not be overlook and should be taken into account in all decision-making regarding future construction completion. The LCA and LCC assessment methodologies may offer important outputs in these decision-making processes: assessment and comparison in alternative investment strategies, determination of a project's viability, 
assessment and concepts of various reconstruction and maintenance methods, choosing from a variety of construction materials and technologies, elements and systems in the context of sustainability.

Author Contributions: J.Š. and M.K. conceived and designed the experiments; J.Š. performed the experiments; J.Š. analyzed the data; J.Š. contributed reagents/materials/analysis tools; J.Š. and M.K. wrote the paper.

Funding: The article presents a partial research result of the VEGA project-1/0557/18 "Research and development of process and product innovations of modern methods of construction in the context of the Industry 4.0 principles".

Acknowledgments: The article presents a partial research result of the VEGA project-1/0557/18 "Research and development of process and product innovations of modern methods of construction in the context of the Industry 4.0 principles".

Conflicts of Interest: The authors declare no conflict of interest.

\section{References}

1. Huttmanová, E. Selected Aspects and Problems of Evaluation of Sustainable Development. 2017. Available online: https://lnk.sk/bjqZ (accessed on 2 October 2017).

2. Mederly, P. Environmentálne Indikátory Trvalo Udržatel'ného Rozvoja. Ph.D. Thesis, Fakulta prírodných vied UKF v Nitre, Nitra, Slovakia, 2009.

3. Tambouratzis, T. Analysing the construction of the environmental sustainability index 2005. Int. J. Environ. Sci. Technol. 2016, 13, 2817-2836. [CrossRef]

4. Klemeš, J.J. Assessing and measuring environmental impact and sustainability. Clean Technol. Environ. 2015, 17, 577-578. [CrossRef]

5. Pintarič, Z.N.; Varbanov, P.S.; Klemeš, J.J.; Kravanja, Z. Evaluating the Economic Efficiency of the Technologies for Greenhouse Gas Footprint Reduction. Chem. Eng. Trans. 2015, 45, 535-540. [CrossRef]

6. Yong, J.Y.; Klemeš, J.J.; Varbanov, P.S.; Huisingh, D. Cleaner energy for cleaner production: Modelling, simulation, optimisation and waste management. J. Clean. Prod. 2016, 111, 1-16. [CrossRef]

7. Ylmaz, M.; Bakis, A. Sustainability in construction. Procedia Soc. Behav. Sci. 2015, 195, 2253-2262. [CrossRef]

8. European Council for an Energy Efficient Economy (ECEEE). Products Covered and Their Status in the EuP Process; ECEEE: Stockholm, Sweden, 2013.

9. European Union (EU). Energy Efficiency, Amending Directives 2009/125/EC and 2010/30/EU and Repealing Directives 2004/8/EC and 2006/32/EC; Directives; Office Journal of the EU: Brussels, Belgium, 2012.

10. International Energy Agency (IEA). Technology Roadmap —Energy Efficient Building Envelopes; OECD: Paris, France, 2013.

11. Smith, R.E.; Timberlake, J. Prefab Architecture: A Guide to Modular Design and Construction; John Wiley \& Sons: Hoboken, NJ, USA, 2011; ISBN 978-0-470-27561-0.

12. Chen, Y.; Okudan, G.E.; Riley, D.R. Sustainable performance criteria for construction method selection in concrete buildings. Autom. Constr. 2010, 19, 235-244. [CrossRef]

13. Burwood, S.; Jess, P. Modern Methods of Construction Evolution or Revolution? A BURA Steering and Development Forum Report; American Research Institute for Policy Development: New York, NY, USA, 2005. Available online: https://pdfs.semanticscholar.org/d7de/2b7518554ae5eef659877c43fa4558b62b3d.pdf (accessed on 1 October 2017).

14. Bragança, L.; Mateus, R.; Koukkari, H. Building Sustainability Assessment. Sustainability 2010, 2, 2010-2023. [CrossRef]

15. Pifko, H. NEED—Navrhovanie Energeticky Efektivnych Domov; Vydavatel'stvo Eurostav: Bratislava, Slovakia, 2017.

16. Farr, D. Sustainable Urbanism: Urban Design with Nature; Wiley: Chicago, IL, USA, 2008; ISBN 047 177751X.

17. World Wide Fund for Nature (WWF). 2018. Available online: https://www.wwf.org.uk/what-we-do/areaof-work/promoting-sustainable-living (accessed on 6 February 2018).

18. Ministry of Environment of the Slovak Republic. 2018. Available online: http://www.minzp.sk/en/ (accessed on 8 February 2018).

19. Klincko, A. Bývanie v 21. Storočí v Košiciach Stratégia Rozvoja Bývania. 2003. Available online: https://www.kosice.sk/static/akcny_plan_byvania.rtf (accessed on 5 February 2018). 
20. Cholujová, M. Ev. č.: Rekt-13369-10618. In Prieskum Záujmu o Domy na Báze Dreva v Banskobystrickom Regióne; Technická Univerzita vo Zvolene: Zvolen, Slovakia, 2011.

21. Pošiváková, T.; Hromada, R.; Veszelits Laktičová, K.; Vargová, M.; Pošivák, J.; Molnár, L. Selected Aspects of Integrated Environmental Management. Ann. Agric. Environ. Med. 2018. [CrossRef]

22. Katunsky, D.; Katunska, J.; Toth, S. Possibility of choices industrial hall object reconstruction. In Proceedings of the 15th International Multidisciplinary Scientific Geoconference SGEM, Albena, Bulgaria, 18-24 June 2015; pp. 389-396. [CrossRef]

23. Bholah, R.; Subratty, A.H. Indoor biological contaminants and symptoms of sick building syndrome in office buildings in Mauritius. Int. J. Environ. Health Res. 2002, 12, 93-98. [CrossRef] [PubMed]

24. Ali, M.; Olaide, O.; Osman, S.B.; Yusof, F. Hygrothermal performance of building envelopes in the tropics under operative conditions: Condensation and mould growth risk appraisal. J. Teknol. 2016, 78, 271-279. [CrossRef]

25. Rajničová, L. Analýza možností využitia LCA v rozhodovacom procese v odpadovom hospodárstve. Novus. Sci. 2007, 1, 489-493.

26. Korytárová, J.; Hromádka, V.; Dufek, Z. Large city circle road Brno. Org. Technol. Manag. Constr. Int. J. 2012, 3, 584-592. [CrossRef]

27. Napolano, L.; Menna, C.; Asprone, D.; Prota, A.; Manfredi, G. LCA-based study on structural retrofit options for masonry buildings. Int. J. Life Cycle Assess. 2015, 20, 23-35. [CrossRef]

28. Napoli, C.; Marcotrigiano, V.; Montagna, M.T. Air sampling procedures to evaluate microbial contamination: A comparison between active and passive methods in operating theatres. BMC Public Health 2012, $12,1$. [CrossRef] [PubMed]

29. Tywoniak, J.; Novák, J. Strategie Nízkoenergetického Stavění, Udržitelný Rozvoj Dřevostavby. 2017. Available online: http:/ / stavba.tzb-info.cz/t.py?t=2\&i=1029 (accessed on 5 September 2017).

30. Strauss, A.; Frangopol, D.M.; Bergmeister, K. Life-Cycle and Sustainability of Civil Infrastructure Systems; CRC: London, UK, 2013.

31. Schau, E.M.; Traverso, M.; Lehmann, A.; Finkbeiner, M. Life Cycle Costing in Sustainability Assessment-A Case Study of Remanufactured Alternators. Sustainability 2011, 3, 2268-2288. [CrossRef]

32. Ding, G.K.C. Sustainable construction-The role of environmental assessment tools. J. Environ. Manag. 2008, 86, 451-464. [CrossRef] [PubMed]

33. Wagner, K. Generation of a Tropically Adapted Energy Performance Certificate for Residential Buildings. Sustainability 2014, 6, 8415-8431. [CrossRef]

34. Vinodh, S.; Jayakrishna, K.; Kumar, V.; Dutta, R. Development of Decision Support System for Sustainability Evaluation: A Case Study. Clean Technol. Environ. Policy 2014, 16, 163-174. [CrossRef]

35. European Union (EU). Sustainability of Construction. Assessment of the Environmental Performance of Buildings. Calculation Methods; EN 15978; NSAI: Dublin, Ireland, 2012.

36. Tsai, C.-Y.; Chang, A.-S. Framework for Developing Construction Sustainability Items: The Example of Highway Design. J. Clean. Prod. 2012, 20, 127-136. [CrossRef]

37. Ali, H.H.; Al Nsairat, S.F. Developing a green building assessment tool for developing countries-Case of Jordan. Build. Environ. 2009, 44, 1053-1064. [CrossRef]

38. Siva, V.; Hoppe, T.; Jain, M. Green Buildings in Singapore; Analyzing a Frontrunner's Sectoral Innovation System. Sustainability 2017, 9, 919. [CrossRef]

39. Hauschild, M.; Jeswiet, J.; Alting, L. From life cycle assessment to sustainable production: Status and perspectives. CIRP Ann. Manuf. Technol. 2005, 54, 1-21. [CrossRef]

40. Lichtenvort, K.; Rebitzer, G.; Huppes, G.; Ciroth, A.; Seuring, S.; Schmidt, W.-P.; Günther, E.; Hoppe, H.; Swarr, T.; Hunkeler, D. Introduction-History of life cycle costing, its categorization, and its basic framework. In Environmental Life Cycle Costing; CRC Press: Boca Raton, FL, USA, 2008.

41. Rebitzer, G.; Nakamura, S. Environmental Life Cycle Costing; CRC Press: Boca Raton, FL, USA, 2008.

42. ISO. Environmental Management-Life Cycle Assessment-Principles and Framework, 2nd ed.; ISO 14040; ISO: Geneva, Switzerland, 2006.

43. ISO. Environmental Management-Life Cycle Assessment-Requirements and Guidelines; ISO 14044; ISO: Geneva, Switzerland, 2006.

44. Kelly, J.; Hunter, K. Life Cycle Costing of Sustainable Design; RICS Research: London, UK, 2009. 
45. ISO. Buildings and Constructed Assets-Service Life Planning, Part 5: Life Cycle Costing; ISO 15686-5; ISO: Geneva, Switzerland, 2017.

46. Faber, A.; Hoppe, T. Co-constructing a sustainable built environment in the Netherlands-Dynamics and opportunities in an environmental sectoral innovation system. Energy Policy 2012, 52, 628-638. [CrossRef]

47. Xie, X.; Lu, Y.; Gou, Z. Green Building Pro-Environment Behaviors: Are Green Users Also Green Buyers? Sustainability 2017, 9, 1703. [CrossRef]

48. Azman, M.N.A.; Ahamad, M.S.S.; Hilmi, N.D. The perspective view of Malaysian industrialized building system (IBS) under IBS precast manufacturing. In Proceedings of the 4th International Engineering Conference-Towards Engineering of 21st Century, Gaza City, Gaza Strip, 15-16 October 2012.

49. Lovell, H.; Smith, S.J. Agencement in housing markets, the case of the UK construction industry. Geoforum 2010, 41, 457-468. [CrossRef]

50. Arif, M.; Egbu, C. Making a case for offsite construction in China. Eng. Constr. Archit. Manag. 2010, 17, 536-548. [CrossRef]

51. Report by the National Audit Office (RNAO). Using Modern Methods of Construction to Build Homes more Quickly and Efficiently; RNAO: London, UK, 2005.

52. Slovak Federation for Processors of Wood (SFPW). 2017. Available online: http://www.zsdsr.sk/en/home (accessed on 4 September 2017).

53. Nässén, J.; Hedenus, F.; Karlsson, S.; Holmberg, J. Concrete vs. wood in buildings-An energy system approach. Build. Environ. 2012, 51, 361-369. [CrossRef]

54. Zgutova, K.; Decky, M.; Sramek, J.; Dreveny, I. Using of Alternative Methods at Earthworks Quality Control. Procedia Earth Planet. Sci. 2015, 15, 263-270. [CrossRef]

55. Olsova, J.; Gašparik, J.; Stefunkova, Z.; Briatka, P. Interaction of the asphalt layers reinforced by glass-fiber mesh. In Proceedings of the 2nd International Conference on Engineering Sciences and Technologies, High Tatras Mountains, Tatranské Matliare, Slovak, 29 June-1 July 2016; pp. 803-808.

56. Gašparik, J.; Gašparík, M. Automated quality excellence evaluation. Gerontechnology 2012, 11, 84. [CrossRef]

57. Sebok, T.; Vondruska, M.; Kulisek, K. Influence of MSFC-type dispersant composition on the performance of soluble anhydrite binders. Cem. Concr. Res. 2001, 31, 1593-1599. [CrossRef]

58. Lupisek, A.; Nehasilova, M.; Mancik, S.; Zelezna, J.; Ruzicka, J.; Fiala, C.; Tywoniak, J.; Hajek, P. Desighn strategies of building with low embodied energy. Proc. Inst. Civ. Eng.-Eng. Sustain. 2017, 170, 65-80. [CrossRef]

59. Minarovičová, K.; Antošová, N. Sustainability of ETICS maintenance technologies. Appl. Mech. Mater. Adv. Archit. Des. Constr. 2016, 820, 194-199. [CrossRef]

60. Woloszyn, M.; Kalamees, T.; Abadie, M.O.; Steeman, M.; Kalagasidis, A.S. The effect of combining a relative-humidity-sensitive ventilation system with the moisture-buffering capacity of materials on indoor climate and energy efficiency of buildings. Build. Environ. 2009, 44, 515-524. [CrossRef]

61. Takano, A.; Hughes, M.; Winter, S. A multidisciplinary approach to sustainable building material selection: A case study in a Finnish context. Build. Environ. 2014, 82, 526-535. [CrossRef]

62. Mesároš, P.; Mandičák, T.; Selín, J. Modern methods for cost management in construction enterprises, Journal of Civil Engineering. Sel. Sci. Pap. 2015, 10, 111-120.

63. Hulinova, Z.; Funtik, T.; Madova, J.; Bistak, A. Effectiveness of costs incurred for labor protection. In Advances and Trends in Engineering Sciences and Technologies II; CRC Press: Boca Raton, FL, USA, 2017; pp. 425-431.

64. European Union (EU). Sustainability of Construction Works-Assessment of Buildings-Part 3: Framework for the Assessment of Social Performance; Prepared by CEN/TC 350/WG 5; EN 15643-3; NSAI: Dublin, Ireland, 2012.

65. European Union (EU). Sustainability of Construction Works-Assessment of Buildings-Part 4: Framework for the Assessment of Economic Performance; Prepared by CEN/TC 350/WG 4; EN 15643-4; NSAI: Dublin, Ireland, 2012.

66. Haas Fertigbau, Slovakia. 2018. Available online: https://www.haas-fertigbau.sk/ (accessed on 5 February 2018).

67. Majumdar, D.; Majhi, B.J.; Dutta, A.; Mandal, R.; Jash, T. Study on possible economic and environmental impacts of electric vehicle infrastructure in public road transport in Kolkata. Clean Technol. Environ. 2015, 17, 1093-1101. [CrossRef]

68. Panepinto, D.; Brizio, E.; Genon, G. Atmospheric pollutants and air quality effects: Limitation costs and environmental advantages (a cost-benefit approach). Clean Technol. Environ. 2014, 16, 1805-1813. [CrossRef]

69. ISO. Buildings and Constructed Assets-Service Life Planning, Part 1: General Principles and Framework; ISO 15686-1; ISO: Geneva, Switzerland, 2011. 
70. Gustavsson, L.; Sathre, R. Variability in energy and carbon dioxide balances of wood and concrete building materials. Build. Environ. 2006, 41, 940-951. [CrossRef]

71. Bhochhibhoya, S.; Pizzol, M.; Achten, W.M.J.; Maskey, R.K.; Zanetti, M.; Cavalli, R. Comparative life cycle assessment and life cycle costing of lodging in the Himalaya. Int. J. Life Cycle Assess. 2017, 22, 1851-1863. [CrossRef]

72. Santi, S.; Pierobon, F.; Corradini, G.; Cavalli, R.; Zanetti, M. Massive wood material for sustainable building design: the Massiv-Holz-Mauer wall system. J. Wood Sci. 2016, 62, 416-428. [CrossRef]

73. Ximenes, A.F.; Grant, T. Quantifying the greenhouse benefits of the use of wood products in two popular house designs in Sydney, Australia. Int. J. Life Cycle Assess. 2013, 18, 891-908. [CrossRef]

74. Silvestre, J.D.; Brito, J.; Pinheiro, M.D. From the new European standards to an environmental, energy and economic assessment of building assemblies from cradle-to-cradle(3E-C2C). Energy Build. 2013, 64, 199-208. [CrossRef]

75. Morel, J.C.; Mesbah, A.; Oggero, M.; Walker, P. Building houses with local materials: Means to drastically reduce the environmental impact of construction. Build. Environ. 2001, 36, 1119-1126. [CrossRef]

76. Blengini, G.A.; Di Carlo, T. The changing role of life cycle phases, subsystems and materials in the LCA of low energy buildings. Energy Build. 2010, 42, 869-880. [CrossRef]

77. Pajchrowski, G.; Noskowiak, A.; Lewandowska, A.; Strykowski, W. Wood as a building material in the light of environmental assessment of full life cycle of four buildings. Constr. Build. Mater. 2014, 52, 428-436. [CrossRef]

78. Upton, B.; Miner, R.; Spinney, M.; Heath, L.S. The greenhouse gas and energy impacts of using wood instead of alternatives in residential construction in the United States. Biomass Bioenergy 2008, 32, 1-10. [CrossRef]

79. Almusaed, A.; Almssad, A. Building materials in eco-energy houses from Iraq and Iran. Case Stud. Constr. Mater. 2015, 2, 42-54. [CrossRef]

80. Glasare, G.; Haglund, P. Climate Impacts of Wood vs. Non Wood Buildings; Sveriges Kommuner och Landsting: Stockholm, Sweden, 2016; ISBN 978-91-7585-377-2.

81. Russell-Smith, S.V.; Lepech, M.D. Cradle-to-gate sustainable target value design: Integrating life cycle assessment and construction management for buildings. JCP 2015, 100, 107-115. [CrossRef]

82. Goldstein, B.; Eriksson, A.H. Livscykelkostnader-Till Vilken Nytta för Miljön och Plånboken? Nordiska Ministerrådet: Köpenhamn, Denmark, 2010.

83. Afshari, A.; Nikolopoulou, C.; Martin, M. Life-Cycle Analysis of Building Retrofits at the Urban Scale-A Case Study in United Arab Emirates. Sustainability 2014, 6, 453-473. [CrossRef]

84. Toosi, H.A.; Balador, Z.; Gjerde, M.; Vakili-Ardebili, A. A life Cycle Cost Analysis and Environmental Assessment on the Photovoltaic System in Buildings: Two Case Studies in Iran. J. Clean Energy Technol. 2018, 6, 134-138. [CrossRef]

85. Alama, M.; Singhb, H. A combined life cycle cost and energy analysis of Vacuum insulation Panels (VIPs) in building applications. In Proceedings of the 13th International Vacuum Insulation Symposium (IVIS), Paris, France, 20-21 September 2017.

86. Dwaikata, L.N.; Ali, K.N. Green Buildings Life Cycle Cost Analysis and Life Cycle Budget Development: Practical Applications. J. Build. Eng. 2018, 18, 303-311. [CrossRef]

87. Marszal, A.J.; Heiselberg, P. Life cycle cost analysis of a multi-storey residential Net Zero Energy Building in Denmark. Energy 2011, 36, 5600-5609. [CrossRef]

88. Carter, T.; Keeler, A. Life-cycle cost-benefit analysis of extensive vegetated roof systems. J. Environ. Manag. 2008, 87, 350-363. [CrossRef] [PubMed]

89. Hasan, A. Optimizing insulation thickness for buildings using life cycle cost. Appl. Energy 1999, 63, 115-124. [CrossRef]

90. Schade, J. Life cycle cost calculation models for buildings. In Proceedings of the 4th Nordic Conference on Construction Economics and Organisation: Development Processes in Construction Mangement, Luleå Tekniska Universitet, Luleå, Sweden, 14-15 June 2007.

(c) 2018 by the authors. Licensee MDPI, Basel, Switzerland. This article is an open access article distributed under the terms and conditions of the Creative Commons Attribution (CC BY) license (http:/ / creativecommons.org/licenses/by/4.0/). 